\title{
Jaringan Syaraf Tiruan Backpropagation Untuk Peramalan Suhu Minimum dan Maksimum, Kelembaban, Tekanan Udara, Jumlah Hari Hujan, dan Curah Hujan Bulanan Di Kota Mataram
}

\author{
(Backpropagation Neural Network for Monthly Minimum and Maximum \\ Temperatures, Humidity, Air Pressure, Number of Rainy Days, and Rainfall \\ Forecasting In Mataram City)
}

\author{
Ida Nyoman Tegeh Adnyana*, I Gede Pasek Suta Wijaya, Mohammad Ali Albar \\ Dept Informatics Engineering, Mataram University \\ Jl. Majapahit 62, Mataram, Lombok NTB, INDONESIA \\ Email: tegeh_add@yahoo.co.id, [gpsutawijaya, mohalialbar]@unram.ac.id
}

*Penulis korespondensi

\begin{abstract}
Climate condition influents on various sectors of human life, such as agriculture. Climate forecasting can be done to help to map the planting period so that agricultural productivity is optimal. An artificial neural network is a method that can be used to forecast the climate in the future. In this research, backpropagation algorithm was used to forecast monthly data on the minimum and maximum temperatures, humidity, air pressure, number of rainy days, and rainfall in Mataram city by applying a hidden layer and two hidden layers, and also applying binary sigmoid and bipolar sigmoid as the activation function. The accuracy of the forecasting result is measured based on MSE (mean square error). Based on the research conducted, the MSE of the testing phase is minimum temperature is $2.65 \times 10-3$, the maximum temperature is $1.97 \times 10-4$, humidity is $2.11 \times 10-3$, air pressure is $2.50 \times 10-3$, the number of rainy days is $7.97 \times$ $10-4$, and rainfall is $1.00 \times 10-3$.
\end{abstract}

Key words: backpropagation, temperature, humidity, air pressure, number of rainy days, rainfall.

\section{PENDAHULUAN}

Kondisi iklim sangat berpengaruh terhadap berbagai sektor kehidupan manusia, salah satunya adalah pertanian. Kondisi cuaca yang tidak menentu dan iklim yang ekstrim, seperti banjir dan kekeringan berkepanjangan dapat berpengaruh terhadap masa tanam dan masa panen yang pada akhirnya dapat menyebabkan kegagalan panen. Untuk menghindari hal tersebut dan menjaga kestabilan hasil produksi dari sektor pertanian, maka perlu dilakukan pemetaan masa tanam. Hal tersebut dapat dilakukan dengan mengetahui keadaan cuaca dan iklim di masa mendatang.

Peramalan iklim merupakan suatu studi yang dapat dilakukan untuk mendapatkan perkiraan keadaan iklim di masa mendatang berdasarkan pada data historis dari keadaan cuaca dan iklim yang telah terjadi sebelumnya.
Di lain pihak, JST (jaringan syaraf tiruan) adalah sebuah metode yang banyak digunakan dalam melakukan suatu peramalan. Namun, kelemahan JST yang terdiri dari layer tunggal membuat perkembangan JST menjadi terhenti pada sekitar tahun 1970-an. Selanjutnya, penemuan backpropagation yang terdiri dari beberapa layer membuka kembali cakrawala penelitian mengenai JST. Terlebih setelah berhasil ditemukannya berbagai aplikasi (pengenalan pola, signal processing, dan peramalan) yang dapat diselesaikan dengan backpropagation yang membuat JST semakin diminati orang [1].

Peramalan dan simulasi data hidroklimatologi, antara lain curah hujan, kelembaban udara, suhu, penyinaran matahari, dan kecepatan angin telah dilakukan menggunakan JST backpropagation dengan studi kasus di daerah Lombok Tengah [2]. Baik pelatihan maupun pengujian metode backpropagation tersebut, dihasilkan tingkat akurasi yang baik yaitu lebih dari $95 \%$. Hal ini menunjukkan metode dan arsitektur JST yang digunakan sangat baik untuk peramalan. Peramalan menggunakan JST backpropagation menggunakan kombinasi hidden neuron dengan alpha juga telah dilakukan untuk memprediksi produksi air bersih di PDAM Purwa Tirta Dharma Kabupaten Grobogan [3]. Pada pengujiannya dihasilkan tingkat akurasi sebesar 95,93\%. Berdasarkan kedua metode tersebut, metode backpropagation dapat digunakan untuk melakkukan peramalan.

Berdasarkan permasalahan yang telah diuraikan tersebut, pada penelitian ini akan dilakukan peramalan terhadap data bulanan suhu minimum dan maksimum, kelembaban, tekanan udara, jumlah hari hujan, dan curah hujan di Kota Mataram. Metode yang digunakan adalah jaringan syaraf tiruan backpropagation. Jumlah 
hidden layer dan hidden neuron yang digunakan akan divariasikan, serta membandingkan antara penerapan fungsi sigmoid biner dan bipolar untuk mendapatkan nilai akurasi hasil peramalan yang terbaik. Kesalahan hasil peramalan akan dievaluasi menggunakan MSE (mean square error).

\section{TINJAUAN PUSTAKA}

Penelitian-penelitian mengenai peramalan curah hujan untuk beberapa daerah telah dilakukan menggunakan metode jaringan syaraf tiruan backpropagation [4][5][6][7]. Penelitian mengenai peramalan curah hujan menggunakan sebuah hidden layer telah dilakuan dengan studi kasus di Kota Medan. Jumlah hidden neuron yang digunakan bervariasi mulai dari lima hingga delapan. Hasil peramalan terbaiknya didapatkan menggunakan lima hidden neuron. Berdasarkan penelitian tersebut diketahui bahwa nilai target error berbanding terbalik dengan jumlah ecpoh [4]. Peramalan curah hujan telah dilakukan dengan studi kasus di Kota Pekanbaru. Pada penelitian ini dilakukan pembobotan secara acak dan pembobotan dengan metode Nguyen-Widrow. Hasil penelitian tersebut menunjukkan metode Nguyen-Widrow menghasilkan niali MSE yang lebih kecil dibandingkan dengan pembobotan secara acak. Penerapan fungsi sigmoid biner menghasilkan akurasi hasil peramalan yang tidak jauh berbeda dengan penerapan fungsi sigmoid bipolar, namun penerapan fungsi sigmoid bipolar menghasilkan akurasi yang lebih baik dibandingkan fungsi sigmoid bipolar [5]. Peramalan curah hujan dilakukan dengan studi kasus pada stasiun BMKG Tenggarong, Kalimantan Timur menggunakan dua hidden layer. MSE yang diperoleh adalah 9,6341 x $10^{-4}$. Hal ini menunjukkan jaringan syaraf tiruan backpropagation dapat memberikan akurasi yang baik untuk meramalkan curah hujan [6]. Peramalan curah hujan sekaligus suhu telah dilakukan dengan studi kasus di Kota Košice. Kinerja terbaik dari sistem peramalan yang dibuat dihasilkan menggunakan delapan hidden neuron. Namun, hasil peramalan dan kinerja dari peramalan suhu lebih baik dibandingkan dengan peramalan curah hujan [7].

Penelitian mengenai peramalan iklim dan cuaca telah dilakukan menggunakan metode jaringan syaraf tiruan backpropagation [2][8]. Penelitian mengenai peramalan hidroklimatologi telah dilakukan terhadap data curah hujan, suhu, kelembaban udara, kecepatan angin, dan lama penyinaran matahari dengan studi kasus di daerah Lombok Tengah. Arsitektur jaringan syaraf tiruan yang dibangun menggunakan dua hidden layer. Akurasi pengujian validasi yang diperoleh adalah 99,76\% [2]. Penelitian mengenai peramalan cuaca telah dilakukan untuk daerah Mumbai, menggunakan dua hidden layer. Peramalan yang dihasilkan memperoleh akurasi sebesar $90 \%$ dan error $0,0773[8]$.
Penelitian mengenai peramalan produksi air bersih menggunakan metode jaringan syaraf tiruan backpropagation dengan studi kasus PDAM (Perusahaan Daerah Air Minum) Purwa Tirta Dharma telah dilakukan. Pada penelitian ini dilakukan kombinasi antara jumlah hidden neuron dengan alpha untuk mencari kombinasi terbaik dalam menghasilkan data peramalan. Peramalan produksi air bersih dilakukan dengan mempertimbangkan korelasi antara jumlah pelanggan, jumlah air terjual, jumlah kehilangan air, dan jumlah debit sumber air. Peramalan dilakukan menggunakan sebuah hidden layer. Hasil peramalan terbaik didapatkan menggunakan kombinasi tujuh hidden neuron dengan alpha 0,7 [3].

Penelitian mengenai perbandingan jaringan syaraf tiruan backpropagation dengan metode-metode peramalan yang lain telah dilakukan [9][10]. Penelitian mengenai peramalan kebutuhan energi listrik jangka panjang di Indonesia sampai tahun 2022 telah dilakukan dengan membandingkan antara metode logika fuzzy dengan jaringan syaraf tiruan backpropagation, dimana pada metode backpropagation yang diterapkan menggunakan dua hidden layer. Nilai error yang dihasilkan menggunakan metode logika fuzzy adalah 8,2413\%, sedangkan pada metode backpropagation adalah 2,8027\% [9]. Peramalan suhu rata-rata di Kairo telah dilakukan dengan membandingkan antara metode jaringan syaraf tiruan backpropagation dan regresi linier berganda. Arsitektur jaringan syaraf tiruan yang digunakan adalah satu hidden layer. Hasil penelitian tersebut menunjukkan metode jaringan syaraf tiruan backpropagation memberikan hasil yang lebih baik dibandingkan dengan metode regresi linier berganda, dimana CC (Coefisien Correlation) yang dihasilkan menggunakan metode jaringan syaraf tiruan adalah 0,971677 sedangkan CC yang dihasilkan menggunakan metode regresi linier berganda adalah 0,942955 [10].

Penelitian mengenai pembuatan sistem informasi berbasis web dengan framework CodeIgniter telah dilakukan. Penelitian mengenai pembuatan sistem informasi berbasis web dengan studi kasus KPN (Koperasi Pegawai Negeri) Universitas Mataram telah dilakukan. Pembuatan sistem informasi tersebut dapat mempermudah ketua, admin, dan anggota dalam mengakses informasi dan melakukan berbagai keperluannya terhadap KPN Universitas Mataram tanpa harus mendatangi KPN Universitas Mataram [11].

Berdasarkan uraian mengenai penelitian-penelitian sebelumnya, dapat diketahui bahwa jaringan syaraf tiruan backpropagation baik digunakan untuk peramalan. Jika dibandingkan dengan metode regresi linier berganda, jaringan syaraf tiruan backpropagation menunjukkan kinerja yang lebih baik [10]. Pada penelitian ini akan dilakukan peramalan terhadap data suhu minimum dan maksimum, kelembaban, tekanan udara, jumlah hari hujan, dan curah hujan dengan studi 
kasus di Kota Mataram. Metode yang digunakan adalah jaringan syaraf tiruan backpropagation dengan satu hidden layer dan dua hidden layer. Sistem peramalan yang dibangun berbasis web dengan framework CodeIgniter. Data yang digunakan dari tahun 2008 hingga 2018 yang didapatkan dari BPS (Badan Pusat Statistik) Kota Mataram dan BMKG (Badan Meteorologi, Klimatologi, dan Geofisika) Stasiun Klimatologi Kediri, Lombok Barat.

\section{METODE PENELITIAN}

Pada penelitian ini, dilakukan peramalan terhadap data bulanan suhu minimum, suhu maksimum, kelembaban, tekanan udara, jumlah hari hujan, dan curah hujan dengan studi kasus di Kota Mataram. Sistem peramalan yang dibangun berbasis web menggunakan framework CodeIgniter. Alur proses pembuatan system peramalan menggunakan metode jaringan syaraf tiruan backpropagation terdiri dari empat tahap, yaitu tahap awal (penyiapan data), tahap pelatihan, tahap pengujian, dan tahap peramalan. Pada tahap awal dilakukan penentuan arsitektur jaringan syaraf tiruan backpropagation yang akan diterapkan. Pada penelitian ini digunakan dua model, yaitu dengan satu hidden layer dan dua hidden layer. Data input yang akan digunakan dalam perhitungan peramalan terlebih dahulu dilakukan normalisasi pada rentang 0,1 hingga 0,9. Proses normalisasi data menggunakan persamaan (1) [12].

$$
x^{\prime}=\frac{0,8(x-a)}{b-a}+0,1
$$

dimana :

$$
\begin{aligned}
& x^{\prime}: \text { data hasil dinormalisasi } \\
& x: \text { data awal } \\
& a: \text { data minimum } \\
& b: \text { data maksimum }
\end{aligned}
$$

Pada tahap pelatihan akan dilakukan perhitungan data dengan algoritma backpropagation yang terdiri dari fase propagasi maju, propagasi balik, dan perubahan bobot. Alur proses pelatihan menggunakan algoritma backpropagation ditunjukkan pada Gambar 1 .

Fase propagasi maju merupakan proses perhitungan untuk menghasilkan data peramalan diawali dari perhitungan data input yang diterima pada unit input dengan setiap bobot yang dimiliki garis penghubung antara unit input dengan hidden neuron. Hasil perhitungan akan diteruskan ke hidden neuron. Hidden neuron kembali melakukan perhitungan data yang diterima dari unit input dengan setiap bobot yang dimiliki garis penghubung antara hidden neuron dengan unit output. Hasil perhitungan tersebut kemudian diteruskan ke unit output dan dijadikan sebagai hasil peramalan. Kesalahan hasil peramalan terhadap data aktualnya akan dihitung menggunakan MSE. Jika nilai kesalahan (MSE) yang dihasilkan sesuai target error, proses pelatihan diakhiri. Namun, jika belum memenuhi target error, fase propagasi balik dilakukan yaitu proses perhitungan peramalan akan diulangi dengan terlebih dahulu menghitung nilai kesalahan yang terjadi mulai dari unit output ke hidden neuron hingga dari hidden neuron ke unit input dilanjutkan dengan fase perubahan bobot yaitu merubah bobot di setiap garis penghubung mulai dari unit output ke hidden neuron hingga dari hidden neuron ke unit input berdasarkan nilai kesalahan yang didapat pada fase propagasi balik. Keseluruhan proses tersebut akan diulangi hingga target error semakin kecil atau terpenuhi.

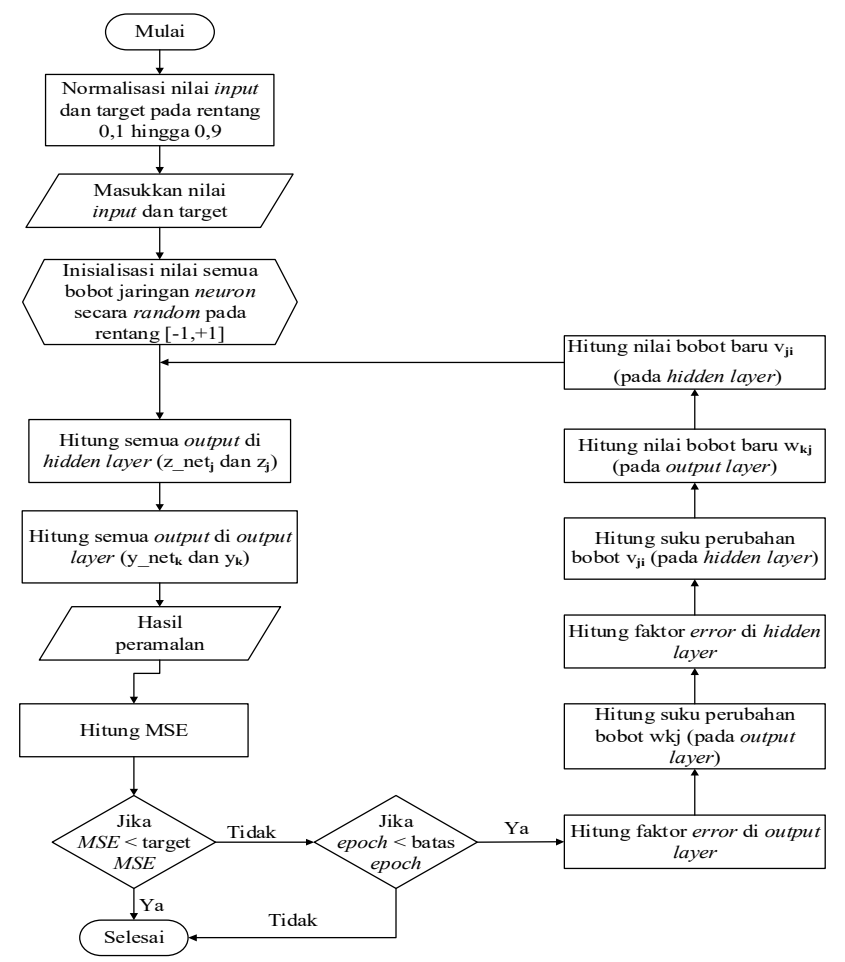

Gambar 1. Alur proses pelatihan dengan metode backpropagation

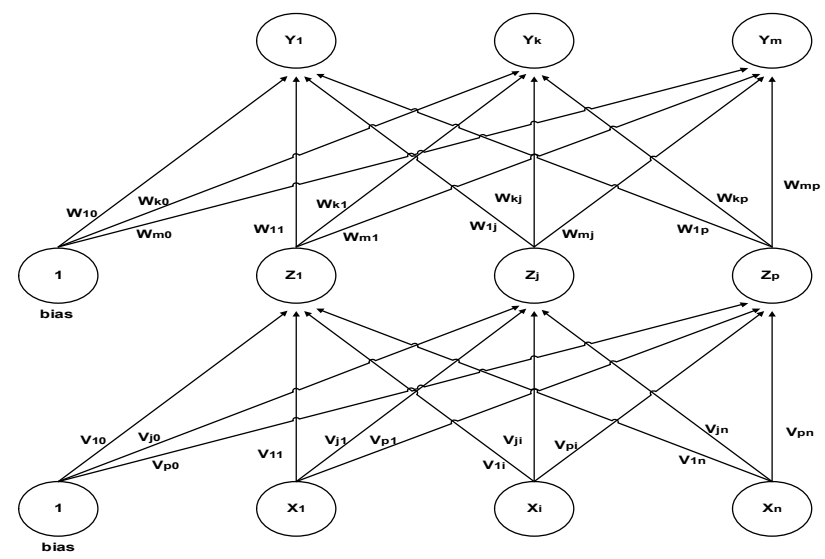

Gambar 2. Arsitektur jaringan syaraf tiruan backpropagation [1]

Backpropagation merupakan metode jaringan syaraf tiruan dengan banyak lapisan yang dapat diterapkan untuk melakukan peramalan berdasarkan kejadian yang bersifat time series. Gambar 1 menunjukkan proses perhitungan pada tahap pelatihan dengan algoritma backpropagation. 
Berikut ini adalah algoritma backpropagation dengan model arsitektur yang ditunjukkan pada Gambar 2 [1].

Langkah 0 : Bobot dengan bilangan acak kecil antara 0 hingga 1 diinisialisasi.

Langkah 1 : Jika kondisi penghentian belum terpenuhi, langkah 2 - 9 dilakukan.

Langkah 2 : Langkah 3 - 8 berikut ini dilakukan untuk setiap data pelatihan.

\section{Fase I : Propagasi Maju}

Langkah 3 : Sinyal input diterima unit input dan diteruskan ke hidden neuron.

Langkah 4 : Output di setiap hidden neuron $\mathrm{z}_{\mathrm{j}}(\mathrm{j}=1,2, \ldots$, p) dihitung.

$$
z_{-} n e t_{j}=\text { bias }+\sum_{i=1}^{n} x_{i} v_{j i}
$$

dimana $:$ bias $=1$.

Fungsi aktivasi sigmoid biner :

$$
z_{j}=f\left(z_{-} n e t_{j}\right)=\frac{1}{1+e^{z_{-} n e t_{j}}}
$$

Fungsi aktivasi sigmoid bipolar :

$$
z_{j}=f\left(z_{-} n e t_{j}\right)=\frac{2}{1+e^{z_{-} n e t_{j}}}-1
$$

Langkah 5 : Output di setiap unit $\mathrm{y}_{\mathrm{k}}(\mathrm{k}=1,2, \ldots, \mathrm{m})$ dihitung.

$$
y_{-} n e t_{k}=\text { bias }+\sum_{j=1}^{p} z_{j} w_{k j}
$$

dimana $:$ bias $=1$.

Fungsi sigmoid biner :

$$
y_{k}=f\left(y_{-} n e t_{k}\right)=\frac{1}{1+e^{y_{-} n e t_{k}}}
$$

Fungsi sigmoid bipolar :

$$
y_{k}=f\left(y_{-} n e t_{k}\right)=\frac{2}{1+e^{y_{-} n e t_{k}}}-1
$$

\section{Fase II : Propagasi Mundur}

Langkah 6 : Faktor $\delta$ unit output dihitung berdasarkan kesalahan di setiap unit output $\mathrm{y}_{\mathrm{k}}(\mathrm{k}=1,2, \ldots, \mathrm{m})$.

$\delta_{k}=\left(t_{k}-y_{k}\right) f^{\prime}\left(\right.$ y_net $\left._{k}\right)=\left(t_{k}-y_{k}\right) y_{k}\left(1-y_{k}\right)$

Suku perubahan bobot $\mathrm{w}_{\mathrm{kj}}$ dihitung dengan laju pembelajaran $\alpha$.

$$
\Delta w_{k j}=\alpha \delta_{k} z_{j}
$$

dimana $: k=1,2, \ldots, m$ dan $j=0,1, \ldots, p$

Langkah 7 : Faktor $\delta$ pada setiap hidden neuron dihitung berdasarkan kesalahan di setiap hidden neuron $\mathrm{z}_{\mathrm{j}}(\mathrm{j}=1$, $2, \ldots, p)$.

$$
\delta \_n e t_{j}=\sum_{k=1}^{m} \delta_{k} w_{k j}
$$

Faktor $\delta$ unit tersembunyi :

$$
\delta_{j}=\delta_{-} n e t_{j} f^{\prime}\left(\mathrm{z}_{-} \text {net }_{j}\right)=\delta_{-} \operatorname{net}_{j} z_{j}\left(1-z_{j}\right)
$$

Suku perubahan bobot $\mathrm{v}_{\mathrm{ji}}$ dihitung.

$$
\Delta v_{j i}=\alpha \delta_{j} x_{i}
$$

dimana $: j=1,2, \ldots, p$ dan $i=0,1, \ldots, n$

Fase III : Perubahan Bobot

Langkah 8 : Semua perubahan bobot dihitung.

Perubahan bobot garis yang menuju ke unit output :

$$
w_{k j}(\text { baru })=w_{k j}(\operatorname{lama})+\Delta w_{k j}
$$

dimana $: k=1,2, \ldots, m$ dan $j=0,1, \ldots, p$

Perubahan bobot garis yang menuju ke hidden neuron :

$$
v_{j i}(b a r u)=v_{j i}(\operatorname{lama})+\Delta v_{j i}
$$

dimana $: j=1,2, \ldots, p$ dan $i=0,1, \ldots, n$

Selanjutnya dilakukan perhitungan nilai MSE untuk mengetahui nilai kesalahan pada sistem. Rumus perhitungan MSE adalah sebagai berikut [12].

$$
M S E=\frac{1}{k} \sum_{k=1}^{n}\left(y_{k}-t_{k}\right)^{2}
$$

Untuk mengevaluasi hasil peramalan dari sistem yang dibuat, digunakan CC (Correlation Coeficient) yang dilambangkan dengan $\mathrm{r}$ dan MAPE (Mean Absolute Percentage Error). Koefisien korelasi menunjukkan seberapa kuat hubungan linier antara dua variabl, dalam hal ini adalah menunjukkan kecocokan antara data aktual dengan hasil peramalan yang dilakukan. Nilainya berkisar antara $[-1,+1]$. Jika nilai koefisien korelasi semakin mendekati 1 , menunjukkan hasil peramalan yang semakin baik [10]. 


$$
r=\frac{\sum_{i=1}^{N}\left(\left(Y_{i}-\bar{Y}\right)\left(X_{i}-\bar{X}\right)\right)}{\sqrt{\sum_{i=1}^{N}\left(Y_{i}-\bar{Y}\right)^{2} \sum_{i=1}^{N}\left(X_{i}-\bar{X}\right)^{2}}}
$$

dimana :

$\mathrm{r}$ : koefisien korelasi

$\mathrm{N}$ : total jumlah output peramalan

$Y_{i}$ : data aktual ke-i

$\bar{Y}$ : rata-rata data aktual

$X_{i}$ : data peramalan ke-i

$\bar{X}$ : rata-rata data peramalan

Untuk mengetahui keakurasian sistem peramalan yang dibuat, digunakan MAPE (mean absolute percentage error). MAPE menunjukkan seberapa besar kesalahan peramalan dengan membandingkan terhadap data aktualnya. Berikut ini adalah rumus untuk menghitung MAPE [3].

$$
M A P E=\frac{\sum_{t=1}^{n} \frac{\left|x_{t}-y_{t}\right|}{x_{t}}}{n} \times 100 \%
$$

dimana :

$x_{t}:$ data aktual ke-t

$y_{t}:$ data peramalan ke-t

$n$ : jumlah data

Sehingga nilai akurasinya adalah [3]:

$$
\text { Akurasi }=100 \%-M A P E
$$

Setelah perhitungan algoritma backpropagation selesai, nilai data output di denormalisasi menggunakan persamaan (14) [12].

$$
x=\frac{\left(x^{\prime}-0,1\right)(b-a)}{0,8}+a
$$

dimana :

$x^{\prime}$ : data hasil dinormalisasi

$x$ : data awal

$a:$ data minimum

$b:$ data maksimum

Pada tahap pengujian perhitungan hanya melalui fase propagasi maju untuk mendapatkan hasil peramalan. Tahap pengujian dilakukan untuk mengetahui tingkat kesalah hasil peramalan berdasarkan nilai MSE yang didapatkan. Pada tahap ini, perhitungan data peramalan dilakukan dengan menggunakan bobot-bobot yang didapatkan pada tahap pelatihan. Alur proses pengujian ditunjukkan pada Gambar 3.

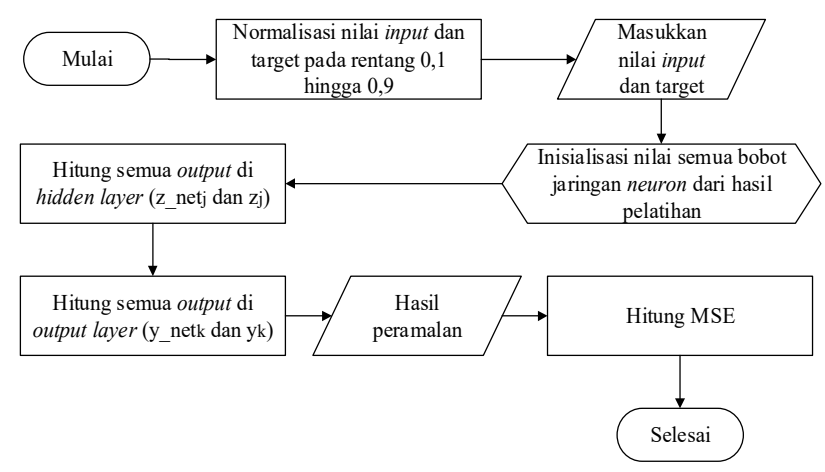

Gambar 3. Alur proses pengujian

Pada tahap peramalan perhitungan hanya melalui fase propagasi maju untuk mendapatkan hasil peramalan. Pada tahap ini, perhitungan data peramalan dilakukan dengan menggunakan bobot-bobot yang didapatkan pada tahap pelatihan. Alur proses peramalan ditunjukkan pada Gambar 4.

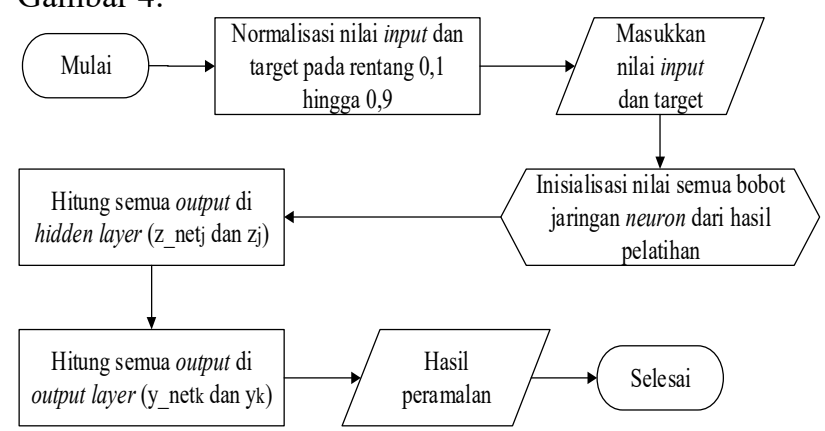

Gambar 4. Alur proses peramalan

Adapun pada penelitian ini dilakukan peramalan dengan memvariasikan nilai dari parameter-parameter antara lain jumlah neuron pada hidden layer, laju pembelajaran, target error, dan fungsi aktivasi. Skenario pelatihan yang dilakukan pada penelitian ini ditunjukkan pada Tabel I.

TABEL I. SKenARio PELATIHAN

\begin{tabular}{|l|l|}
\hline \multicolumn{1}{|c|}{ Parameter } & \multicolumn{1}{c|}{ Nilai } \\
\hline Hidden layer 1 & $10,30,50$ \\
\hline Hidden layer 2 & 10 \\
\hline Laju pembelajaran & 0,5 \\
\hline Target error & $1 \times 10^{-4}$ \\
\hline Fungsi aktivasi & Sigmoid biner, sigmoid bipolar \\
\hline Maksimal epoch & 3000 \\
\hline Elemen iklim yang diteliti & $\begin{array}{l}\text { Suhu minimum, suhu maksimum, } \\
\text { kelembaban, tekanan udara, jumlah } \\
\text { hari hujan, curah hujan }\end{array}$ \\
\hline
\end{tabular}

Pada setiap skenario pelatihan, batas maksimal epoch yang diberikan adalah 3000. Target error yang digunakan adalah $1 \times 10^{-4}$ [2]. Laju pembelajaran yang digunakan yaitu 0,5 [8]. Hidden layer yang diterapkan ada dua, yaitu penggunaan satu hidden layer yang terdiri dari 10, 30, dan 50 neuron [10], dan penggunaan dua hidden layer yang 
terdiri dari 10, 30, dan 50 neuron pada hidden layer pertama serta 10 neuron pada hidden layer kedua $[2][8][10]$.

\section{HASIL DAN PEMBAHASAN}

\section{A. Tahap Awal}

Data yang digunakan dalam penelitian ini adalah data suhu minimum, suhu maksimum, kelembaban, tekanan udara, jumlah hari hujan, dan curah hujan di Kota Mataram yang didapatkan dari BPS (Badan Pusat Statistik) Kota Mataram dan Stasiun Klimatologi BMKG (Badan Meteorologi, Klimatologi, dan Geofisika) Kediri, Lombok Barat. Data yang didapatkan tersebut adalah data aktual suhu minimum, suhu maksimum, kelembaban, tekanan udara, jumlah hari hujan, dan curah hujan per bulan dari tahun 2008 hingga 2018. Data dari tahun 2008 hingga 2016 digunakan untuk tahap pelatihan, data tahun 2017 untuk tahap pengujian, dan data tahun 2018 digunakan untuk membandingkan hasil peramalan di tahun tersebut.

\section{B. Tahap Pelatihan}

Pelatihan dilakukan sesuai skenario yang telah ditentukan yang ditunjukkan pada Tabel I. Pelatihan dilakukan untuk mendapatkan bobot-bobot yang akan digunakan untuk melakukan perhitungan peramalan.

\section{B.1. Suhu minimum}

Tahap pelatihan dilakukan untuk mengenali pola historis dari data suhu minimum. Setiap bobot yang didapatkan dari hasil pelatihan terbaik akan digunakan untuk tahap pengujian dan peramalan. Hasil pelatihan terbaik dipilih berdasarkan nilai rata-rata MSE terkecil.

TABEL II. Hasil Pelatihan Suhu Minimum

\begin{tabular}{|c|c|c|c|c|}
\cline { 2 - 5 } \multicolumn{1}{c|}{} & \multicolumn{2}{|c|}{$\begin{array}{c}\text { Jumlah hidden neuron } \\
\text { pada hidden layer ke- }\end{array}$} & \multicolumn{2}{c|}{ MSE } \\
\cline { 2 - 5 } & $\mathbf{1}$ & $\mathbf{2}$ & $\begin{array}{c}\text { Sigmoid } \\
\text { biner }\end{array}$ & $\begin{array}{c}\text { Sigmoid } \\
\text { bipolar }\end{array}$ \\
\hline \multirow{4}{*}{$\begin{array}{c}\text { Satu } \\
\text { hidden } \\
\text { layer }\end{array}$} & 10 & - & $7,55 \times 10^{-5}$ & $7,46 \times 10^{-5}$ \\
\cline { 2 - 5 } & 30 & - & $4,32 \times 10^{-5}$ & $6,63 \times 10^{-5}$ \\
\cline { 2 - 5 } $\begin{array}{c}\text { Dua } \\
\text { hidden } \\
\text { lyaer }\end{array}$ & 50 & - & $3,11 \times 10^{-5}$ & $5,10 \times 10^{-5}$ \\
\cline { 2 - 5 } & 10 & 10 & $6,78 \times 10^{-5}$ & $8,79 \times 10^{-5}$ \\
\cline { 2 - 5 } & 30 & 10 & $7,29 \times 10^{-5}$ & $8,22 \times 10^{-5}$ \\
\hline
\end{tabular}

Tabel II menunjukkan bahwa penerapan fungsi sigmoid biner maupun bipolar baik digunakan untuk melakukan peramalan suhu minimum. Hasil pelatihan data suhu minimum terbaik didapatkan dengan menggunakan sebuah hidden layer yang terdiri dari 50 neuron dengan menerapkan fungsi sigmoid biner. MSE yang dihasilkan yaitu $3,11 \times 10^{-5}$.

\section{B.2. Suhu maksimum}

Tahap pelatihan dilakukan untuk mengenali pola historis dari data suhu maksimum. Setiap bobot yang didapatkan dari hasil pelatihan terbaik akan digunakan untuk tahap pengujian dan peramalan. Hasil pelatihan terbaik dipilih berdasarkan nilai rata-rata MSE terkecil.
TABEL III. Hasil Pelatihan Suhu Maksimum

\begin{tabular}{|c|c|c|c|c|}
\cline { 2 - 5 } \multicolumn{1}{c|}{} & \multicolumn{2}{c|}{$\begin{array}{c}\text { Jumlah hidden neuron } \\
\text { pada hidden layer ke- }\end{array}$} & \multicolumn{2}{c|}{ MSE } \\
\cline { 2 - 5 } \multicolumn{1}{c|}{} & $\mathbf{1}$ & $\mathbf{2}$ & $\begin{array}{c}\text { Sigmoid } \\
\text { biner }\end{array}$ & $\begin{array}{c}\text { Sigmoid } \\
\text { bipolar }\end{array}$ \\
\hline \multirow{3}{*}{$\begin{array}{c}\text { Satu } \\
\text { hidden } \\
\text { layer }\end{array}$} & 10 & - & $9,04 \times 10^{-5}$ & $8,58 \times 10^{-5}$ \\
\cline { 2 - 5 } & 30 & - & $6,29 \times 10^{-5}$ & $7,68 \times 10^{-5}$ \\
\cline { 2 - 5 } & 50 & - & $3,90 \times 10^{-5}$ & $4,71 \times 10^{-5}$ \\
\hline \multirow{2}{\text{Dua}}{$\begin{array}{c}\text { hidden } \\
\text { lyaer }\end{array}$} & 10 & 10 & $7,37 \times 10^{-5}$ & $8,89 \times 10^{-5}$ \\
\cline { 2 - 5 } & 30 & 10 & $7,56 \times 10^{-5}$ & $8,92 \times 10^{-5}$ \\
\cline { 2 - 5 } & 50 & 10 & $7,99 \times 10^{-5}$ & $8,39 \times 10^{-5}$ \\
\hline
\end{tabular}

Tabel III menunjukkan bahwa penerapan fungsi sigmoid biner maupun bipolar baik digunakan untuk melakukan peramalan suhu maksimum. Hasil pelatihan data suhu maksimum terbaik didapatkan dengan menggunakan sebuah hidden layer yang terdiri dari 50 neuron dengan menerapkan fungsi sigmoid biner. MSE yang dihasilkan yaitu $3,90 \times 10^{-5}$.

\section{B.3. Kelembaban}

Tahap pelatihan dilakukan untuk mengenali pola historis dari data kelembaban. Setiap bobot yang didapatkan dari hasil pelatihan terbaik akan digunakan untuk tahap pengujian dan peramalan. Hasil pelatihan terbaik dipilih berdasarkan nilai rata-rata MSE terkecil.

TABEL IV. Hasil Pelatihan Kelembaban

\begin{tabular}{|c|c|c|c|c|}
\cline { 2 - 5 } \multicolumn{1}{c|}{} & \multicolumn{2}{c|}{$\begin{array}{c}\text { Jumlah hidden neuron } \\
\text { pada hidden layer ke- }\end{array}$} & \multicolumn{2}{c|}{ MSE } \\
\cline { 2 - 5 } \multicolumn{1}{c|}{} & $\mathbf{1}$ & $\mathbf{2}$ & $\begin{array}{c}\text { Sigmoid } \\
\text { biner }\end{array}$ & $\begin{array}{c}\text { Sigmoid } \\
\text { bipolar }\end{array}$ \\
\hline \multirow{3}{*}{$\begin{array}{c}\text { Satu } \\
\text { hidden } \\
\text { layer }\end{array}$} & 10 & - & $7,93 \times 10^{-5}$ & $7,06 \times 10^{-5}$ \\
\cline { 2 - 5 } & 30 & - & $4,33 \times 10^{-5}$ & $6,15 \times 10^{-5}$ \\
\cline { 2 - 5 } & 50 & - & $3,38 \times 10^{-5}$ & $5,12 \times 10^{-5}$ \\
\hline \multirow{2}{\text{Dua}}{$\begin{array}{c}\text { hidden } \\
\text { lyaer }\end{array}$} & 10 & 10 & $8,04 \times 10^{-5}$ & $9,08 \times 10^{-5}$ \\
\cline { 2 - 5 } & 30 & 10 & $7,89 \times 10^{-5}$ & $8,44 \times 10^{-5}$ \\
\cline { 2 - 5 } & 50 & 10 & $7,71 \times 10^{-5}$ & $8,54 \times 10^{-5}$ \\
\hline
\end{tabular}

Tabel IV menunjukkan bahwa bahwa penerapan fungsi sigmoid biner maupun bipolar baik digunakan untuk melakukan peramalan kelembaban. Hasil pelatihan data kelembaban terbaik didapatkan dengan menggunakan sebuah hidden layer yang terdiri dari 50 neuron dengan menerapkan fungsi sigmoid biner. MSE yang dihasilkan yaitu $3,38 \times 10^{-5}$.

\section{B.4. Tekanan udara}

Tahap pelatihan dilakukan untuk mengenali pola historis dari data tekanan udara. Setiap bobot yang didapatkan dari hasil pelatihan terbaik akan digunakan untuk tahap pengujian dan peramalan. Hasil pelatihan terbaik dipilih berdasarkan nilai rata-rata MSE terkecil.

Tabel V menunjukkan bahwa bahwa penerapan fungsi sigmoid biner maupun bipolar baik digunakan untuk melakukan peramalan tekanan udara. Hasil pelatihan data tekanan udara terbaik didapatkan dengan menggunakan sebuah hidden layer yang terdiri dari 50 neuron dengan 
menerapkan fungsi sigmoid biner. MSE yang dihasilkan yaitu $3,35 \times 10^{-5}$.

TABEL V. Hasil Pelatihan Tekanan Udara

\begin{tabular}{|c|c|c|c|c|}
\cline { 2 - 5 } \multicolumn{1}{c|}{} & \multicolumn{2}{|c|}{$\begin{array}{c}\text { Jumlah hidden neuron } \\
\text { pada hidden layer ke- }\end{array}$} & \multicolumn{2}{c|}{ MSE } \\
\cline { 2 - 5 } & $\mathbf{1}$ & $\mathbf{2}$ & $\begin{array}{c}\text { Sigmoid } \\
\text { biner }\end{array}$ & $\begin{array}{c}\text { Sigmoid } \\
\text { bipolar }\end{array}$ \\
\hline \multirow{4}{*}{$\begin{array}{c}\text { Satu } \\
\text { hidden } \\
\text { layer }\end{array}$} & 10 & - & $8,33 \times 10^{-5}$ & $7,30 \times 10^{-5}$ \\
\cline { 2 - 5 } & 30 & - & $4,83 \times 10^{-5}$ & $4,57 \times 10^{-5}$ \\
\hline \multirow{2}{*}{$\begin{array}{c}\text { Dua } \\
\text { hidden } \\
\text { lyaer }\end{array}$} & 50 & - & $3,35 \times 10^{-5}$ & $5,87 \times 10^{-5}$ \\
\cline { 2 - 5 } & 10 & 10 & $8,21 \times 10^{-5}$ & $9,02 \times 10^{-5}$ \\
\cline { 2 - 5 } & 30 & 10 & $7,97 \times 10^{-5}$ & $8,32 \times 10^{-5}$ \\
\hline
\end{tabular}

\section{B.5. Jumlah hari hujan}

Tahap pelatihan dilakukan untuk mengenali pola historis dari data jumlah hari hujan. Setiap bobot yang didapatkan dari hasil pelatihan terbaik akan digunakan untuk tahap pengujian dan peramalan. Hasil pelatihan terbaik dipilih berdasarkan nilai rata-rata MSE terkecil.

TABEL VI. Hasil Pelatihan Jumlah Hari Hujan

\begin{tabular}{|c|c|c|c|c|}
\cline { 2 - 5 } \multicolumn{1}{c|}{} & \multicolumn{2}{|c|}{$\begin{array}{c}\text { Jumlah hidden neuron } \\
\text { pada hidden layer ke- }\end{array}$} & \multicolumn{2}{c|}{ MSE } \\
\cline { 2 - 5 } & $\mathbf{1}$ & $\mathbf{2}$ & $\begin{array}{c}\text { Sigmoid } \\
\text { biner }\end{array}$ & $\begin{array}{c}\text { Sigmoid } \\
\text { bipolar }\end{array}$ \\
\hline \multirow{4}{*}{$\begin{array}{c}\text { Satu } \\
\text { hidden } \\
\text { layer }\end{array}$} & 10 & - & $8,11 \times 10^{-5}$ & $7,56 \times 10^{-5}$ \\
\cline { 2 - 5 } & 30 & - & $4,84 \times 10^{-5}$ & $4,43 \times 10^{-5}$ \\
\hline \multirow{2}{*}{$\begin{array}{c}\text { Dua } \\
\text { hidden } \\
\text { lyaer }\end{array}$} & 50 & - & $3,37 \times 10^{-5}$ & $5,68 \times 10^{-5}$ \\
\cline { 2 - 5 } & 10 & 10 & $8,11 \times 10^{-5}$ & $8,45 \times 10^{-5}$ \\
\cline { 2 - 5 } & 30 & 10 & $7,67 \times 10^{-5}$ & $8,61 \times 10^{-5}$ \\
\hline
\end{tabular}

Tabel VI menunjukkan bahwa bahwa penerapan fungsi sigmoid biner maupun bipolar baik digunakan untuk melakukan peramalan jumlah hari hujan. Hasil pelatihan data jumlah hari hujan terbaik didapatkan dengan menggunakan sebuah hidden layer yang terdiri dari 50 neuron dengan menerapkan fungsi sigmoid biner. MSE yang dihasilkan yaitu $3,37 \times 10^{-5}$.

\section{B.6. Curah hujan}

Tahap pelatihan dilakukan untuk mengenali pola historis dari data curah hujan. Setiap bobot yang didapatkan dari hasil pelatihan terbaik akan digunakan untuk tahap pengujian dan peramalan. Hasil pelatihan terbaik dipilih berdasarkan nilai rata-rata MSE terkecil.

Tabel VII menunjukkan bahwa bahwa penerapan fungsi sigmoid biner maupun bipolar baik digunakan untuk melakukan peramalan curah hujan. Hasil pelatihan data curah hujan terbaik didapatkan dengan menggunakan sebuah hidden layer yang terdiri dari 50 neuron dengan menerapkan fungsi sigmoid biner. MSE yang dihasilkan yaitu $3,08 \times 10^{-5}$.
TABEL VII. Hasil Pelatihan Curah Hujan

\begin{tabular}{|c|c|c|c|c|}
\cline { 2 - 5 } \multicolumn{1}{c|}{} & \multicolumn{2}{c|}{$\begin{array}{c}\text { Jumlah hidden neuron } \\
\text { pada hidden layer ke- }\end{array}$} & \multicolumn{2}{c|}{ MSE } \\
\cline { 2 - 5 } \multicolumn{1}{c|}{} & $\boldsymbol{1}$ & $\boldsymbol{2}$ & $\begin{array}{c}\text { Sigmoid } \\
\text { biner }\end{array}$ & $\begin{array}{c}\text { Sigmoid } \\
\text { bipolar }\end{array}$ \\
\hline \multirow{4}{*}{$\begin{array}{c}\text { Satu } \\
\text { hidden } \\
\text { layer }\end{array}$} & 10 & - & $7,90 \times 10^{-5}$ & $8,03 \times 10^{-5}$ \\
\cline { 2 - 5 } & 30 & - & $5,31 \times 10^{-5}$ & $6,19 \times 10^{-5}$ \\
\cline { 2 - 5 } & 50 & - & $3,08 \times 10^{-5}$ & $4,09 \times 10^{-5}$ \\
\hline $\begin{array}{c}\text { Dua } \\
\text { hidden } \\
\text { lyaer }\end{array}$ & 10 & 10 & $8,21 \times 10^{-5}$ & $8,89 \times 10^{-5}$ \\
\cline { 2 - 5 } & 30 & 10 & $8,23 \times 10^{-5}$ & $7,84 \times 10^{-5}$ \\
\cline { 2 - 5 } & 50 & 10 & $8,27 \times 10^{-5}$ & $7,99 \times 10^{-5}$ \\
\hline
\end{tabular}

\section{Tahap Pengujian}

Pengujian dilakukan untuk mengetahui akurasi atau tingkat kesalahan dari data peramalan yang dihasilkan. Perhitungan peramalan pada tahap pengujian dilakukan menggunakan bobot-bobot yang telah didapatkan dari tahap pelatihan. Tahap pengujian dilakukan untuk mengetahui tingkat kesalahan data peramalan yang dihasilkan menggunakan bobot-bobot yang didapatkan dari hasil tahap pelatihan terbaik. Pada tahap pelatihan, penerapan fungsi aktivasi sigmoid biner menunjukkan hasil yang lebih baik daripada sigmoid bipolar.

TABEL VIII. HASL PENGUJIAN

\begin{tabular}{|l|l|c|c|}
\hline \multicolumn{1}{|c|}{ Elemen Iklim } & \multicolumn{1}{c|}{ MSE } & CC & MAPE \\
\hline Suhu minimum & $2,65 \times 10^{-3}$ & 0,89 & $1,58 \%$ \\
\hline Suhu maksimum & $1,97 \times 10^{-4}$ & 0,98 & $0,41 \%$ \\
\hline Kelembaban & $2,11 \times 10^{-3}$ & 0,92 & $0,75 \%$ \\
\hline Tekanan udara & $2,50 \times 10^{-3}$ & 0,92 & $0,05 \%$ \\
\hline Jumlah hari hujan & $7,97 \times 10^{-4}$ & 0,99 & - \\
\hline Curah hujan & $1,00 \times 10^{-3}$ & 0,99 & - \\
\hline
\end{tabular}

Hasil pengujian ditunjukkan pada Tabel III. Hasil pengujian tersebut didapatkan dengan menggunakan arsitektur backpropagation terbaik berdasarkan hasil pelatihan. Berdasarkan hasil yang didapatkan, penerapan fungsi sigmoid biner baik digunakan untuk peramalan data suhu minimum, suhu maksimum, kelembaban, tekanan udara, jumlah hari hujan, dan curah hujan. CC (Correlation Coeficient) yang dihasilkan pada tahap pengujian nilainya mendekati 1 , hal ini menunjukkan adanya kecocokan yang baik antara data aktual dengan hasil peramalan. MAPE (Mean Absolute Percentage Error) yang dihasilkan mendekati 0 , hal ini menunjukkan hasil peramalan tersebut memiliki persentase tingkat kesalahan yang kecil. Namun, pada pengujian data jumlah hari hujan dan curah hujan, nilai MAPE tidak dapat dihitung karena adanya data actual yang bernilai 0 (dengan kata lain tidak terjadi hujan pada bulan tertentu). Dalam hal ini, pengujian dilakukan terhadap data tahun 2017, dimana pada bulan Agusuts tidak turun hujan. 


\section{Tahap Peramalan}

Peramalan dilakukan untuk memperkirakan data suhu minimum, suhu maksimum, kelembaban, tekanan udara, jumlah hari hujan, dan curah hujan di tahun 2018. Perhitungan peramalan dilakukan menggunakan bobotbobot yang telah didapatkan pada tahap pelatihan dan telah diuji keakurasiannya pada tahap pengujian. Arsitektur jaringan syaraf tiruan yang dibangun untuk melakukan peramalan dipilih berdasarkan hasil pengujian terbaik.

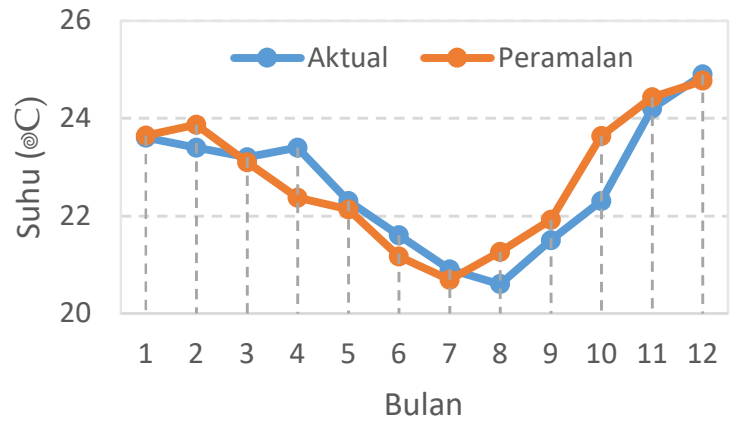

Gambar 5. Peramalan suhu minimum dengan input dari tahun 2010 hingga 2017 untuk peramalan tahun 2018

Peramalan suhu minimum dilakukan untuk tahun 2018. Kemudian hasil peramalan tersebut akan dicocokan dengan data aktual pada tahun 2018. Hasil peramalan suhu minimum ditunjukkan pada Gambar 5. Nilai koefisien korelasi yang dihasilkan adalah 0,72. MAPE yang dihasilkan pada peramalan data suhu minimum ini adalah $2,95 \%$, sehingga persentase akurasi peramalannya adalah $97,05 \%$. Hal tersebut menunjukkan hasil peramalan pada tahap pelatihan memiliki akurasi yang tinggi. Kesenjangan antara data aktual dengan hasil peramalan pada bulan Oktober terjadi karena adanya perubahan suhu minimum antara data pelatihannya (tahun 2016) dengan data pengujiannya (tahun 2017).

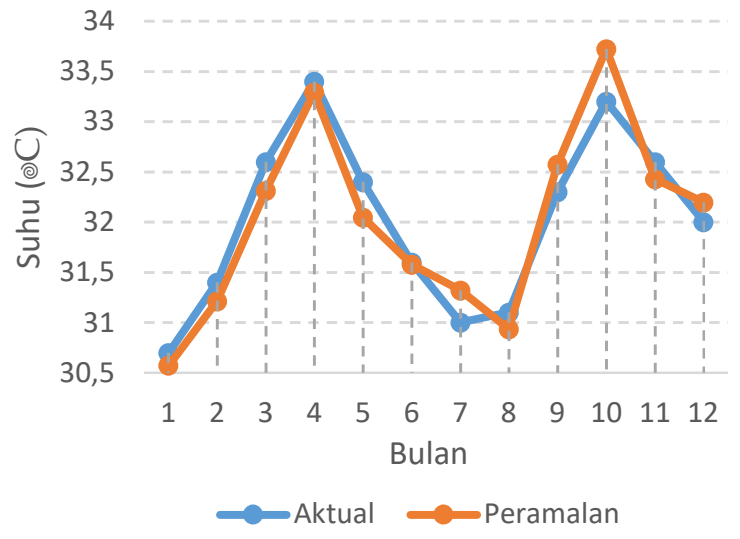

Gambar 6. Peramalan suhu maksimum dengan input dari tahun 2010 hingga 2017 untuk peramalan tahun 2018

Peramalan suhu maksimum dilakukan untuk tahun 2018. Kemudian hasil peramalan tersebut akan dicocokan dengan data aktual pada tahun 2018. Hasil peramalan suhu maksimum ditunjukkan pada Gambar 6. Nilai koefisien korelasi yang dihasilkan adalah 0,96. MAPE yang dihasilkan pada peramalan data suhu maksimum ini adalah $0,71 \%$, sehingga persentase akurasi peramalannya adalah $99,29 \%$. Hal tersebut menunjukkan hasil peramalan pada tahap pelatihan memiliki akurasi yang tinggi.

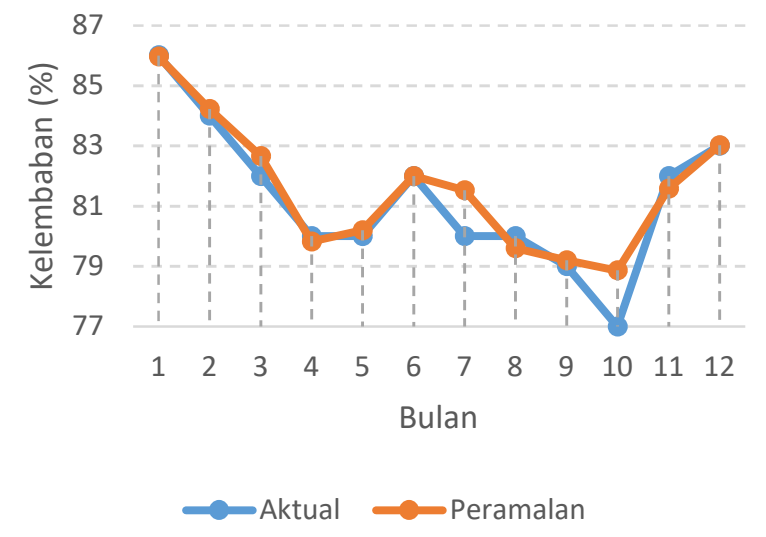

Gambar 7. Peramalan kelembaban dengan input dari tahun 2010 hingga 2017 untuk peramalan tahun 2018

Peramalan kelembaban dilakukan untuk tahun 2018. Kemudian hasil peramalan tersebut akan dicocokan dengan data aktual pada tahun 2018. Hasil peramalan kelembaban ditunjukkan pada Gambar 7. Nilai koefisien korelasi yang dihasilkan adalah 0,96. MAPE yang dihasilkan pada peramalan kelembaban ini adalah $0,60 \%$, sehingga persentase akurasi peramalannya adalah $99,40 \%$. Hal tersebut menunjukkan hasil peramalan pada tahap pelatihan memiliki akurasi yang tinggi.

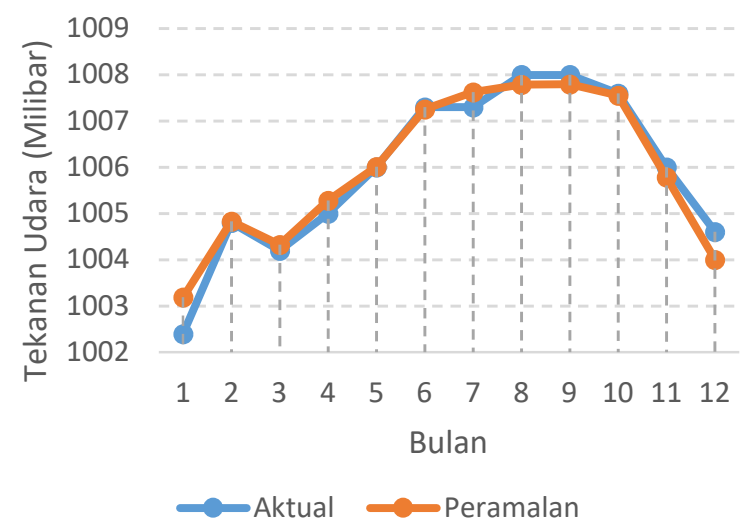

Gambar 8. Peramalan tekanan udara dengan input dari tahun 2010 hingga 2017 untuk peramalan tahun 2018

Peramalan tekanan udara dilakukan untuk tahun 2018. Kemudian hasil peramalan tersebut akan dicocokan dengan data aktual pada tahun 2018. Hasil peramalan tekanan udara ditunjukkan pada Gambar 8. Nilai koefisien korelasi yang dihasilkan adalah 0,98 . MAPE yang dihasilkan pada peramalan tekanan udara ini adalah $0,02 \%$, sehingga persentase akurasi peramalannya adalah 99,98\%. Hal tersebut menunjukkan hasil peramalan pada tahap pelatihan memiliki akurasi yang tinggi. 


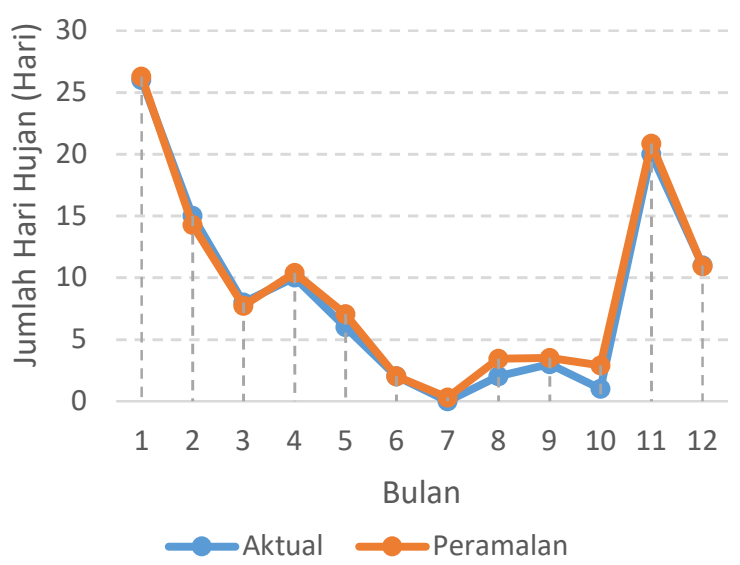

Gambar 9. Peramalan jumlah hari hujan dengan input dari tahun 2010 hingga 2017 untuk peramalan tahun 2018

Peramalan jumlah hari hujan dilakukan untuk tahun 2018. Kemudian hasil peramalan tersebut akan dicocokan dengan data aktual pada tahun 2018. Hasil peramalan jumlah hari hujan ditunjukkan pada Gambar 9. Nilai koefisien korelasi yang dihasilkan adalah 0,99 . Hal tersebut menunjukkan hasil peramalan pada tahap pelatihan memiliki akurasi yang tinggi. Nilai MAPE pada peramalan jumlah hari hujan tidak dapat dihitung karena terdapat data aktual yang nilainya 0 (tidak turun hujan pada bulan Juli).

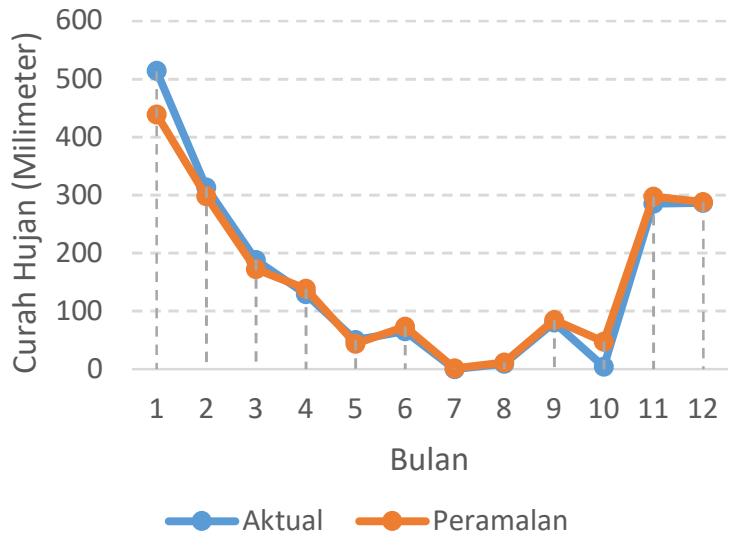

Gambar 10. Peramalan curah hujan dengan input dari tahun 2010 hingga 2017 untuk peramalan tahun 2018

Peramalan curah hujan dilakukan untuk tahun 2018. Kemudian hasil peramalan tersebut akan dicocokan dengan data aktual pada tahun 2018. Hasil peramalan curah hujan ditunjukkan pada Gambar 10. Nilai koefisien korelasi yang dihasilkan adalah 0,99. Hal tersebut menunjukkan hasil peramalan pada tahap pelatihan memiliki akurasi yang tinggi. Nilai MAPE pada peramalan curah hujan tidak dapat dihitung karena terdapat data aktual yang nilainya 0 (tidak turun hujan pada bulan Juli).

\section{KESIMPULAN DAN SARAN}

Beberapa hal yang dapat disimpulkan berdasarkan hasil penelitian ini adalah sebagai berikut : a) Penggunaan sebuah hidden layer yang terdiri dari 50 neuron dengan menerapkan fungsi sigmoid biner menghasilkan peramalan yang terbaik dengan nilai MSE pada pelatihan data pada suhu minimum $3,11 \times 10^{-5}$, suhu maksimum $3,90 \times$ $10^{-5}$, kelembaban $3,38 \times 10^{-5}$, tekanan udara 3,35 x $10^{-5}$, jumlah hari hujan $3,37 \times 10^{-5}$, dan curah hujan $3,08 \times 10^{-5}$.

b) Ketersediaan data pelatihan yang sedikit dan perubahan lingkungan yang ekstrem dapat menghasilkan akurasi peramalan yang relatif rendah, seperti yang ditunjukkan hasil peramalan pada suhu minimum bulan Oktober tahun 2018.

Beberapa hal yang dapat disarankan untuk pengembangan penelitian ini kedepannya adalah sebagai berikut :

a) Pada penelitian ini data yang didapatkan terbatas, yaitu dari tahun 2008 hingga 2018. Sehingga, untuk meningkatkan hasil peramalan iklim, diperlukan data yang lebih banyak untuk dapat mengenali pola data iklim yang lebih baik.

b) Peramalan iklim pada penelitian ini juga terbatas pada suhu minimum, suhu maksimum, kelembaban, tekanan udara, jumlah hari hujan, dan curah. Sedangkan masih terdapat beberapa elemen iklim yang lainnya, seperti kecepatan angin, arah angin, dan lamanya penyinaran matahari.

c) Peramalan iklim dapat dilakukan dengan mempertimbangkan korelasi antara elemenelemen iklim.

\section{DAFTAR PUSTAKA}

[1] J. J. Siang, Jaringan Syaraf Tiruan Dan Pemrogramannya Menggunakan Matlab, I. Yogyakarta: Andi, 2005.

[2] S. Suhaidi, E. Febriana, H. RPN, and I. Ardiansyah, "ANN Back Propagation for Forecasting and Simulation Hydroclimatology Data," in Prosiding Seminar Nasional Pendidik dan Pengembang Pendidikan Indonesia dengan Tema "Membangun Generasi Berkarakter Melalui Pembelajaran Inovatif,” 2017, pp. 553559.

[3] A. P. Widodo, Suhartono, E. A. Sarwoko, and Z. Firdaus, "Akurasi Model Prediksi Metode Backpropagation Menggunakan Kombinasi Hidden Neuron Dengan Alpha," J. Mat., vol. 20, pp. 79-84, 2017.

[4] Y. Andrian and E. Ningsih, "Prediksi Curah Hujan Di Kota Medan Menggunakan Metode Backpropagation Neural Network," in Seminar Nasional Informatika, 2014, pp. 184-189.

[5] L. Handayani and M. Adri, "Penerapan JST (Backpropagation) untuk Prediksi Curah Hujan (Studi Kasus: Kota Pekanbaru)," in Seminar Nasional Teknologi Informasi, Komunikasi dan Industri (SNTIKI) 7, 2015, pp. 238-247. 
[6] Mislan, Haviluddin, S. Hardwinarto, Sumaryono, and M. Aipassa, "Rainfall Monthly Prediction Based on Artificial Neural Network: A Case Study in Tenggarong Station, East Kalimantan Indonesia," in International Conference on Computer Science and Computational Intelligence (ICCSCI 2015), 2015, pp. 142-151.

[7] R. Jakša, M. Zelenáková, J. Košcák, and H. Hlavatá, "Local Prediction of Precipitation Based on Neural Network," in "Environmental Engineering" 10th International Conference, 2017, pp. 1-5.

[8] M. Narvekar, P. Fargose, and D. Mukhopadhyay, "Weather Forecasting Using ANN with Error Backpropagation Algorithm," in Proceedings of the International Conference on Data Engineering and Communication Technology, 2017, pp. 629639.

[9] N. Nurkholiq, T. Sukmadi, and A. Nugroho,
“Analisis Perbandingan Metode Logika Fuzzy Dengan Jaringan Syaraf Tiruan Backpropagation Pada Peramalan Kebutuhan Energi Listrik Jangka Panjang Di Indonesia Sampai Tahun 2022," TRANSIENT, vol. 3, no. 2, 2014.

[10] M. A. Ashour, S. A. ElZahaby, and M. I. Abdalla, "Backpropagation Neural Network Approach For Mean Temperature Prediction," Int. J. Recent Res. Appl. Stud., vol. 29, no. 1, pp. 12-18, 2016.

[11] D. M. Harja, S. E. Anjarwani, and A. Zubaidi, "Sistem Informasi Koperasi Pegawai Negeri ( KPN ) Universitas Mataram Berbasis Web," $J$. Comput. Sci. Informatics Eng., vol. 2, no. 2, pp. 143-149, 2018.

[12] R. N. Fadhilah and R. V. H. Ginardi, "Penentuan Harga dengan Metode Back Propagation pada Aplikasi E-Commerce CariKos Berbasis Web," J. Tek. ITS, vol. 6, no. 2, pp. A495-A500, 2017. 